pemphigus vulgaris: PEMPULS trial. Arch Dermatol 2006;142:570-6.

21 Beissert S, Werfel T, Frieling U et al. A comparison of oral methylprednisolone plus azathioprine or mycophenolate mofetil for the treatment of pemphigus. Arch Dermatol 2006;142:1447-54.

22 Ahmed AR, Spigelman Z, Cavacini LA, Posner MR. Treatment of pemphigus vulgaris with rituximab and intravenous immune globulin. $\mathrm{N} \mathrm{Engl} \mathrm{J} \mathrm{Med}$ 2006;355:1772-9.

23 Joly P, Mouquet H, Roujeau JC et al. A single cycle of rituximab for the treatment of severe pemphigus. $\mathrm{N} \mathrm{Engl} \mathrm{J} \mathrm{Med}$ 2007;357:545-52.

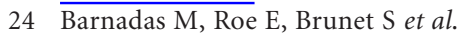
Therapy of paraneoplastic pemphigus with rituximab: a case report and review of literature. J Eur Acad Dermatol Venereol 2006;20:69-74.

25 Schmidt E, Seitz CS, Benoit S, Bröcker EB, Groebeler M. Rituximab in autoimmune bullous diseases: mixed responses and adverse effects. Br J Dermatol 2007;156:352-6.

Address for correspondence:

Dr R Groves, Clinical

Immunodermatology, St John's Institute of Dermatology, Guy's Hospital, Great Maze Pond, London SE1 9RT.

Email: richard.groves@kcl.ac.uk

\section{Cutaneous manifestations of cancer} and chemotherapy Brighton and Sussex University Hospitals NHS Trust, Brighton General Hospital

It is important for general physicians to be aware of cutaneous signs and symptoms that may indicate the presence of an underlying malignancy. Broadly there are four categories to consider:

- cutaneous metastasis/direct tumour spread

- inherited cancer syndromes with cutaneous manifestations

- cutaneous markers of exposure to carcinogens, and

- paraneoplastic syndromes.

Knowledge of the cutaneous manifestations of systemic and targeted cancer therapy is also important.

\section{Cutaneous metastasis/direct tumour spread}

In general, the skin is an uncommon site of distant metastases (incidence 2-4\%). ${ }^{1}$ The most common primary sites in men are lung (24\%), colon (19\%) and oral squamous cell carcinoma (12\%) and in women breast (69\%), colon (19\%) and
Emma Topham, Consultant Dermatologist, ovary $(4 \%) .^{2}$ Lesions appear as firm, red or blue nodules, often multiple and close to the site of the primary tumour. The scalp is a well documented site of metastasis for breast, lung and renal cancer. Sister Mary Joseph's nodule refers to a periumbilical nodule that can be associated with stomach cancer.

Direct infiltration of the skin is seen with carcinoma erysipeloides, which can be misdiagnosed as cellulitis, and carcinoma en cuirasse, a hard infiltrated plaque. Both are most commonly associated with breast cancer. Paget's disease is an intra-epidermal carcinoma seen in the nipple and areola area (mammary Paget's) or anogenital and axillary skin (extramammary Paget's). ${ }^{3}$ Paget's disease of the breast presents as unilateral, sharply demarcated nipple eczema or erosion, often with bleeding or nipple discharge, in association with underlying non-invasive carcinoma. Extramammary Paget's disease is characterised by an itchy, moist, well-defined erythematous plaque, typically in the anogenital area and most common in elderly women. It is often misdiagnosed as psoriasis or Bowen's disease (squamous carcinoma in situ). It is associated with a local adnexal tumour in $25 \%$ of cases and with an internal malignancy, intraductal adenocarcinoma of the breast or

\section{Key Points}

Direct infiltration of the skin with cancer can mimic cellulitis (carcinoma erysipeloides) or scleroderma (carcinoma en cuirasse)

Extramammary Paget's disease presents with persistent red plaques in the anogenital or axillary area

Specific cutaneous lesions can be markers of internal cancer (inherited cancer syndromes or genodermatoses); for example, sebaceous carcinoma/adenoma can be a marker of bowel cancer in Muir-Torre syndrome

Dermatomyositis is associated with underlying malignancy in $15-41 \%$ of cases

Epidermal growth factor receptor inhibitors are associated with a papulopustular facial rash, the severity of which is positively correlated with tumour response to treatment

KEY WORDS: acral erythema, cutaneous metastasis, epidermal growth factor receptor inhibitors, genodermatoses, paraneoplastic syndromes 
usually from the genitourinary (GU) or gastrointestinal (GI) tract, in a further $12 \% .{ }^{4}$ Vulval disease is more commonly associated with GU tract cancer and perianal disease with GI tract cancer.

\section{Inherited cancer syndromes}

Genetic cancer syndromes (genodermatoses) combine characteristic cutaneous features with a predisposition to internal malignancy. These include skinGI polyposis syndromes such as Gardner and Peutz-Jeghers syndromes. In MuirTorre syndrome sebaceous adenomas and carcinomas are associated with cancer of the GI $(61 \%)$ or GU (22\%) tract. $^{5}$ The internal cancers can be multiple but are usually indolent. ${ }^{6}$ The detailed cutaneous and internal manifestations, inheritance pattern and malignant risk of these conditions, as well as for Cowden syndrome, multiple endocrine neoplasia type $2 \mathrm{~b}$ and neurofibromatosis, are detailed in Table 1. This list is not exhaustive; more detailed reviews, including rarer syndromes, are available. $^{1}$

\section{Cutaneous markers of exposure to environmental carcinogens}

Environmental carcinogens include arsenic, ionising radiation and vinyl chloride. Cutaneous effects of exposure and associated neoplasms have been reviewed elsewhere. ${ }^{7}$

\section{Paraneoplastic syndromes}

Paraneoplastic syndromes may indicate the presence of an underlying malignancy. There are a large number of these syndromes (Table 2) and they have a variable association with malignancy. This review article will focus on pointers suggestive of underlying malignancy in selected conditions.

\section{Cushing's syndrome}

Ectopic production of adrenocorticotrophic hormone $(\mathrm{ACTH})$ resulting in

Table 1. Inherited cancer syndromes, their clinical features and malignancy risk.

\begin{tabular}{|c|c|c|c|}
\hline \multirow[b]{2}{*}{ Syndrome* } & \multicolumn{2}{|l|}{ Features } & \multirow[b]{2}{*}{ Malignancy risk } \\
\hline & Cutaneous & Internal & \\
\hline Gardner & $\begin{array}{l}\text { Osteomas, epidermoid cysts, } \\
\text { desmoid tumours, fibroma, } \\
\text { lipoma }\end{array}$ & $\begin{array}{l}\text { Adenomatous polyps } \\
\text { large bowel 3rd-4th } \\
\text { decade. } \\
\text { Dental abnormalities. } \\
\text { Bilateral congenital } \\
\text { hypertrophy of retinal } \\
\text { pigment epithelium }\end{array}$ & $\begin{array}{l}\text { 50-100\% carcinoma } \\
\text { upper and lower Gl tract } \\
\text { (colon, rectum, } \\
\text { duodenum, ampulla of } \\
\text { vater). } \\
\text { Thyroid carcinoma risk } \\
\text { greater than general } \\
\text { population }\end{array}$ \\
\hline Peutz-Jeghers & $\begin{array}{l}\text { Pigmented macules lips, buccal } \\
\text { mucosa, hands, feet. } \\
\text { Appear in infancy, childhood, } \\
\text { later fade }\end{array}$ & $\begin{array}{l}\text { Hamartomas GI, } \\
\text { respiratory and GU tracts. } \\
\text { Intussusception children }\end{array}$ & $\begin{array}{l}3-30 \% \text {. } \\
\text { GI malignancy up to } \\
12 \% \text {. } \\
\text { Increased risk gonadal } \\
\text { tumours, carcinoma lung } \\
\text { and breast }\end{array}$ \\
\hline Cowden & $\begin{array}{l}\text { Facial warty trichilemmoma, } \\
\text { oral mucosa papillomatosis } \\
\text { (cobblestones), acral keratoses, } \\
\text { lipoma, angioma }\end{array}$ & $\begin{array}{l}\text { Fibrocystic breast disease, } \\
\text { thyroid adenoma, Gl } \\
\text { polyposis, ovarian cysts }\end{array}$ & $\begin{array}{l}\text { Breast cancer } 30 \% \\
\text { women. } \\
\text { Increased risk thyroid and } \\
\text { uterine carcinoma }\end{array}$ \\
\hline Muir-Torre & $\begin{array}{l}\text { Sebaceous adenoma, carcinoma, } \\
\text { epithelioma, keratoacanthoma }\end{array}$ & Gl polyps & $\begin{array}{l}100 \% \text { risk malignancy. } \\
61 \% \mathrm{Gl}, 22 \% \mathrm{GU} \text { cancer. } \\
\text { Often multiple cancers, } \\
\text { but clinically indolent }\end{array}$ \\
\hline $\begin{array}{l}\text { Multiple endocrine } \\
\text { neoplasia type } 2 b\end{array}$ & $\begin{array}{l}\text { Small smooth nodules lips, } \\
\text { buccal mucosa, hands, feet. } \\
\text { Appear in childhood }\end{array}$ & $\begin{array}{l}\text { Multiple neuromas. } \\
\text { Medullary thyroid carcinoma. } \\
\text { Phaeochromocytoma. } \\
50 \% \text { patients show } \\
\text { complete triad }\end{array}$ & $\begin{array}{l}85 \% \text { medullary thyroid } \\
\text { carcinoma. } \\
\text { Prophylactic total } \\
\text { thyroidectomy in early } \\
\text { childhood }\end{array}$ \\
\hline Neurofibromatosis & $\begin{array}{l}\text { Café au lait macules, } \\
\text { neurofibroma, pigmented } \\
\text { hamartoma iris }\end{array}$ & $\begin{array}{l}\text { Intellectual impairment, } \\
\text { short stature, seizures, } \\
\text { precocious puberty, Gl } \\
\text { symptoms from mucosal } \\
\text { neurofibromas }\end{array}$ & $\begin{array}{l}\text { 3-15\%. } \\
\text { Malignant schwannoma, } \\
\text { neurofibrosarcoma, } \\
\text { phaeochromocytoma, } \\
\text { carcinoid, astrocytoma, } \\
\text { melanoma }\end{array}$ \\
\hline
\end{tabular}


Cushing's syndrome is seen with smallcell lung cancer, carcinoid tumours, neural crest, pancreatic and medullary thyroid carcinoma and thymoma. Features suggestive of ectopic production rather than pituitary dependent Cushing's disease include:

- rapid onset of progressive symptoms

- weight loss

- severe muscle wasting

- marked hyperpigmentation

- hypokalaemia

- diabetes, and

- plasma ACTH above 200 ng litre $^{-1}$.

Severe hirsutism or virilisation suggests an adrenal tumour, which should be associated with low or undetectable plasma ACTH. Failure of plasma cortisol levels to suppress with a high-dose dexamethasone test is seen with ectopic ACTH production or an adrenal tumour. The ACTH level will differentiate these and computed tomography scanning can help localise the tumour.

\section{Carcinoid syndrome}

Cutaneous features of carcinoid syndrome include transient deep red or purple flushing of the head and neck and oedema. Telangiectasia, cyanosis, pellagra and features of Cushing's syndrome can also be seen. ${ }^{7}$ The flushing is associated with systemic features including diarrhoea, cramping abdominal pain, asthma and right-sided heart failure. GI tract carcinoid tumours account for $85 \%$ of cases. ${ }^{7}$ Biologically active peptides released by these tumours are removed in the portal circulation, indicating that hepatic metastases are already present at the time of symptom onset. Bronchial and ovarian carcinoids (15\% of cases) can produce symptoms early in the course of the disease.

\section{Necrolytic migratory erythema}

A persistent erythematous scaly rash with annular borders, particularly affecting perioral, genital and flexural areas, is characteristic of necrolytic migratory erythema. There is often a painful glossitis and angular stomatitis. It is associated with glucagonoma of the pancreas. Over $50 \%$ of patients have metastases at the time of presentation.

\section{Acanthosis nigricans}

Acanthosis nigricans, a diffuse, velvety hyperpigmentation and thickening of flexural areas (eg axillae, groin, neck, inframammary area), progresses to a condition with a verrucous or papillomatous appearance. Pointers that suggest a malignant cause include:

- onset after 40 years

- more extensive and severe involvement

- mucosal lesions

- exaggeration of normal skin markings on the knuckles and palms (tripe hands), and

- weight loss and wasting.

Associated malignancies include GI (particularly stomach) or GU tract, breast, lung or lymphoma. Onset of the disease can predate or mirror the onset of the malignancy.

\section{Dermatomyositis}

Adult-onset dermatomyositis can be associated with malignancy. Estimates of

\section{Table 2. Paraneoplastic syndromes.}

- acanthosis nigricans

- acanthosis palmaris

- acquired ichthyosis

- amyloidosis

- carcinoid syndrome

- cryoglobulinaemia

- Cushing's syndrome

- dermatomyositis

- erythroderma

- Leser-Trelat sign

- migratory erythema*

- migratory thrombophlebitis

- multicentric reticulohistiocytosis

- paraneoplastic acrokeratosis (Bazex's syndrome)

- paraneoplastic pemphigus

- pruritus

- $\quad$ pyoderma gangrenosum

- Sweet's syndrome

*necrolytic migratory erythema, erythema gyratum repens. the risk vary from $15-41 \% .{ }^{8,9}$ The most common associated cancers are breast, lung, colon, pancreas and ovary. They may be diagnosed at the same time as or after the diagnosis of dermatomyositis. ${ }^{9}$

Cutaneous manifestations include:

- a heliotrope periorbital rash, often with associated oedema

- Gottron's papules over the knuckles

- periungual telangiectasia, and

- poikiloderma (a triad of atrophy, pigmentation and telangiectasia).

\section{Paraneoplastic pemphigus}

A form of pemphigus, paraneoplastic pemphigus, is seen predominantly with haematological malignancy. It presents with particularly severe mucous membrane ulceration, blisters and erosions, predominantly on the upper body and palmoplantar target lesions. Diagnosis is made on histological and immunofluorescence findings.

\section{Cutaneous manifestations of systemic and targeted cancer therapy}

Non-specific cutaneous manifestations of traditional cytotoxic chemotherapy such as alopecia, xerosis and mucositis are well-known. Other cutaneous side effects include extravasation, hyperpigmentation of skin, hair, mucosae or nails, and acral erythema. Acral erythema (palmar-plantar erythrodysaesthesia syndrome/hand-foot syndrome) is most commonly seen with 5 -fluorouracil and its prodrug capecitabine, as well as with doxorubicin and cytarabine. ${ }^{10}$ It presents with a prodrome of tingling on the palms and soles, progressing over the course of a few days to burning pain, tenderness and oedema associated with well demarcated erythematous plaques. It resolves following cessation of chemotherapy, often with peeling.

New targeted cancer therapies include signal transduction inhibitors, encompassing epidermal growth factor receptor (EGFR) inhibitors and multikinase inhibitors (Table 3). Both groups have well documented cutaneous side effects. 
Table 3. New targeted cancer therapies: signal transduction inhibitors.

$\begin{array}{ll}\text { Epidermal growth factor } & \text { receptor } \\ \text { inhibitors: } & \\ \text { - small molecule } & \text { gefitinib } \\ \text { tyrosine kinase } & \text { erlotinib } \\ \text { inhibitors } & \text { lapatinib } \\ \text { - monoclonal } & \text { cetuximab } \\ \text { antibodies } & \text { panitumumab } \\ \text { Multikinase inhibitors: } & \text { imatinib } \\ & \text { dasatinib } \\ & \text { nilotinib } \\ & \text { sorafenib } \\ & \text { sunitinib }\end{array}$

\section{Epidermal growth factor receptor inhibitors}

EGFR is a transmembrane protein inducing cell proliferation, migration and angiogenesis via a variety of signalling mechanisms. EGFR inhibitors are used in the advanced stages of malignancies which overexpress the receptor, including colorectal cancer and squamous cell carcinoma of head neck (cetuximab), pancreatic cancer (erlotinib) and non-small cell lung cancer (erlotinib and gefitinib). EGFR is constitutively expressed in many normal epithelial tissues including the skin and hair follicles, and cutaneous side effects of treatment are common (Table 4). The most frequent cutaneous side effect is a papulopustular eruption, affecting $24-91 \%$ of patients, depending on the drug used. ${ }^{11}$ It is most common in patients treated with cetuximab and is characterised by multiple follicular or

pustular lesions on the face, scalp, upper chest and back but may extend to the extremities and abdomen. ${ }^{12}$ Crusting is seen in severe cases and an absence of comedones. There is a dose-dependent relationship between severity and incidence of the eruption. Several studies have shown a relationship between severity of the eruption and length of progression free and overall survival benefit following treatment. The eruption typically begins in the first two weeks of treatment and is reversible following treatment withdrawal. ${ }^{13}$

Case reports and reviews have described benefit with emollients, antibiotic treatment for secondary infection, standard acne treatments (topical retinoids and antibiotics, oral tetracyclines) and, if necessary, dose reduction or cessation. Isotretinoin treatment of cetuximab eruptions has been described in three case reports.

Other cutaneous side effects of EGFR inhibitors include xerosis, nail changes (paronychia and pyogenic granuloma), hair abnormalities (brittle, fine, curly scalp hair, long eyebrows), pigmentary change and telangiectasia. ${ }^{14}$

\section{Multikinase inhibitors}

Multikinase inhibitors include imatinib and second-generation agents used in chronic myeloid leukaemia and GI stromal tumours, and sorafenib and sunitinib used in renal cell carcinoma. A rash/desquamation and acral erythema develop in two-thirds of patients treated

\section{Table 4. Cutaneous side effects of epidermal growth factor inhibitors.}

\begin{tabular}{|c|c|}
\hline Site & Abnormalities \\
\hline Hair & $\begin{array}{l}\text { Long eyelashes, eyebrows } \\
\text { Brittle, curly scalp hair }\end{array}$ \\
\hline Nail & $\begin{array}{l}\text { Paronychia } \\
\text { Pyogenic granuloma } \\
\text { Fissuring }\end{array}$ \\
\hline Mucous membrane & Mucositis \\
\hline Skin & $\begin{array}{l}\text { Papulopustular reaction } \\
\text { Xerosis } \pm \text { pruritus } \\
\text { Hypersensitivity reactions (including flushing, } \\
\text { urticaria, anaphylaxis) } \\
\text { Telangiectasia } \\
\text { Hyperpigmentation }\end{array}$ \\
\hline
\end{tabular}

with sorafenib and mild-to-moderate facial oedema is reported in $50 \%$ patients given sunitinib. ${ }^{11}$

\section{Conclusions}

An awareness of cutaneous manifestations of cancer can mean earlier diagnosis and possibly improved survival of affected patients. Cutaneous manifestations of cancer include metastasis, paraneoplastic syndromes and genetic cancer syndromes; these may present to general physicians in a variety of specialties. Cutaneous manifestations of systemic cancer therapies include specific side effects of targeted therapies, such as the papulopustular eruption seen with EGFR inhibitors and characteristic clinical presentations such as acral erythema.

\section{References}

1 Poole S, Fenske NA. Cutaneous markers of internal malignancy. I. Malignant involvement of the skin and the genodermatoses. J Am Acad Dermatol 1993;28:1-13.

2 Brownstein MH, Helwig EB. Patterns of cutaneous metastasis. Arch Dermatol 1972;105:862-8

3 Kanitakis J. Mammary and extramammary Paget's disease. J Eur Acad Dermatol Venereol 2007;21:581-90.

4 Chanda JJ. Extramammary Paget's disease: prognosis and relationship to internal malignancy. J Am Acad Dermatol 1985;13:1009-14.

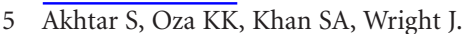
Muir-Torre syndrome: case report of a patient with concurrent jejunal and ureteral cancer and a review of the literature. $J A m$ Acad Dermatol 1999;41(5 Pt 1):681-6.

6 Schwartz RA, Torre DP. The Muir-Torre syndrome: a 25-year retrospect. J Am Acad Dermatol 1995;33:90-104.

7 Poole S, Fenske NA. Cutaneous markers of internal malignancy. II. Paraneoplastic dermatoses and environmental carcinogens. J Am Acad Dermatol 1993;28(2 Pt 1):147-64.

8 Basset-Seguin N, Roujeau JC, Gherardi R et al. Prognostic factors and predictive signs of malignancy in adult dermatomyositis. Arch Dermatol 1990;126:633-7.

9 Sigurgeirsson B, Lindelöf B, Edhag O, Allander E. Risk of cancer in patients with dermatomyositis or polymyositis. A population-based study. $\mathrm{N} \mathrm{Engl} \mathrm{J} \mathrm{Med}$ 1992;326:363-7.

10 Susser WS, Whitaker-Worth DL, GrantKels. Mucocutaneous reactions to chemotherapy. J Am Acad Dermatol 1999;40:367-98. 
11 Heidary N, Naik H, Burgin S. Chemotherapeutic agents and the skin: an update. J Am Acad Dermatol 2008;58:545-70.

12 Robert C, Soria JC, Spatz A et al. Cutaneous side-effects of kinase inhibitors and blocking antibodies. Lancet Oncol 2005;6:491-500.

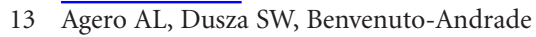
$\mathrm{C}$ et al. Dermatologic side effects associated with the epidermal growth factor receptor inhibitors. J Am Acad Dermatol 2006;55:657-70.

14 Hu JC, Sadeghi P, Pinter-Brown LC, Yashar S, Chiu MW. Cutaneous side effects of epidermal growth factor receptor inhibitors: clinical presentation, pathogenesis, and management. J Am Acad Dermatol 2007;56:317-26.

Address for correspondence:

Dr E Topham, Brighton and Sussex

University Hospitals NHS Trust, Brighton General Hospital, Elm Grove, Brighton BN2 3EW.

Email: emma.topham@bsuh.nhs.uk

\section{The skin in general medicine}

Sasha Dhoat, Locum Consultant Dermatologist; Malcolm Rustin, Consultant Dermatologist

Royal Free Hospital, London

KEY WORDS: skin, lyme disease, Kawasaki disease, hand, foot and mouth disease

Cutaneous manifestations of systemic disorders are common in general medicine and can be important presenting features of internal disease. ${ }^{1,2}$ This review is not comprehensive but highlights the most frequent and important entities.

\section{Infections}

\section{Lyme disease (or borreliosis)}

The most common tick-borne disease in the northern hemisphere is lyme disease. It is transmitted to humans through the bite of an ixodes tick infected with spirochetes Borrelia afzelii or Borrelia garinii (most commonly in Europe) or Borrelia burgdorfei (in the USA). Cases of lyme disease confirmed by UK laboratories have increased tenfold since records began in 1986. Several hundred cases are reported every year, mainly in the southwestern regions of the country during summer months. The disease develops in three stages:

- 1st stage: in $50-75 \%$ of patients the classical rash of erythema chronicum migrans occurs up to four weeks after the tick bite (Fig 1). The annular erythema gradually spreads outwards from the site of the bite; it is usually at least $5 \mathrm{~cm}$ in diameter and may develop central clearing, bruising or necrosis.

- 2nd stage: this may be followed by lesions of multiple secondary erythema migrans, musculoskeletal symptoms (60\%) (often migratory joint pain with or without joint swelling), neurological manifestations $(15 \%)$ (meningitis, facial cranial nerve paralysis and radicular neuropathies) or, less commonly, cardiovascular complications (8\%), including varying degrees of atrioventricular block).

- $3 r d$ stage: in $60 \%$ of untreated cases the next stage begins at least seven months after the primary infection. It can manifest as intermittent pain and swelling of the knees and hips, which may progress to chronic arthritis (10\%). Occasionally, polyneuropathy or encephalopathy may develop.

Diagnosis and treatment. The history of a tick bite and skin eruption is highly characteristic and the diagnosis is primarily clinical. ${ }^{3}$ Serological testing (ELISA and Western blot) is sensitive, but not specific; both tests may be negative early in the disease and they do not accurately distinguish active from past infection. Lyme disease can be confirmed only by culture, although this is a low yield procedure. Treatment with doxycycline $200 \mathrm{mg}$ od for one month should be initiated early to prevent complications.

\section{Tuberculides}

Tuberculides are cutaneous hypersensitivity reactions to tuberculosis (TB)

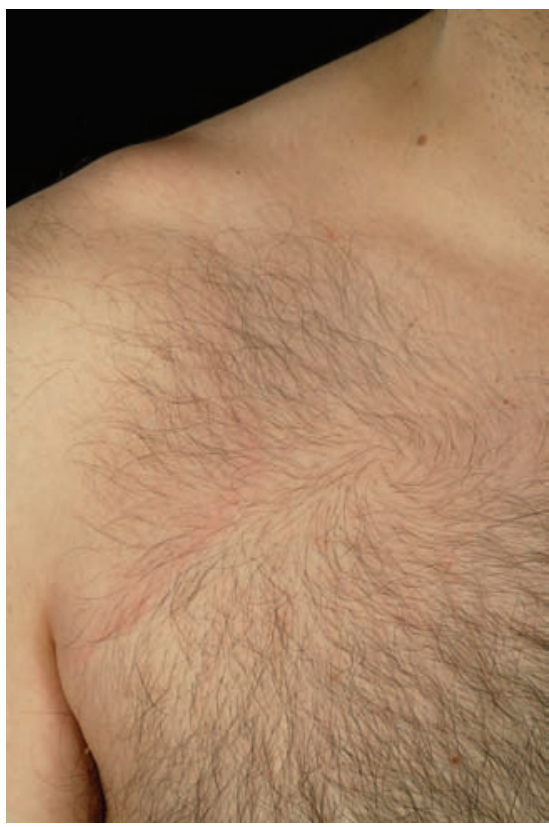

Fig 1. Erythema chronicum migrans. 